НАУКОВИЙ ВІСНИК

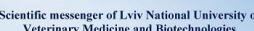

1

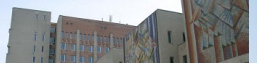

$4^{3}$

СЕРЯ: ВЕТЕРИНАРНН НАУКИ

Том 22 № 100

2020

Науковий вісник Дьвівського національного університету ветеринарної медицини та біотехнологій імені С.3. Гжицького. Серія: Ветеринарні науки

\author{
Scientific Messenger of Lviv National University
} of Veterinary Medicine and Biotechnologies. Series: Veterinary sciences

UDC 636.597.082.09

\title{
Microscopic structure of the rectum of the domestic duck
}

\author{
D. S. Makhotina, M. M. Kushch, O. E. Bondarenko \\ Kharkiv State Zooveterinary Academy, Kharkiv, Ukraine
}

Article info

Received 30.09.2020

Received in revised form 02.11 .2020

Accepted 03.11.2020

Kharkiv State Zooveterinary Academy, Mala Danilivka, Dergachi district, Kharkiv region, 62341, Ukraine.

Tel.: +38-057-635-75-27

E-mail: makhotina.diana@gmail.com
Makhotina, D. S., Kushch, M. M., \& Bondarenko, O. E. (2020). Microscopic structure of the rectum of the domestic duck. Scientific Messenger of Lviv National University of Veterinary Medicine and Biotechnologies. Series: Veterinary sciences, 22(100), 41-49. doi: $10.32718 /$ nvlvet 10008

As a rule, researchers pay less attention to the features of the large intestine than to the small intestine. The purpose of the study was to determine the features of the microscopic structure of the rectum of ducks during the first year of the postnatal period of ontogenesis. For histological examinations, the material was selected from Ukrainian white-breasted ducks of 9 age groups: 1-, 3-, 7-, 14-, 21-day-old, 1-, 2-, 6-monthold and 1-year-old. Morphometric parameters of microstructures were set on cross sections of the midgut. The general change pattern in the morphometric parameters of the microstructures of the rectum of ducks was their increase, which was asynchronous and uneven. There was observed an active intestinal morphogenesis continued, as evidenced by the process of formation of villi and crypts in the group of 1-3-day-old ducks. The most intensive morphometric parameters of the rectum changed in the first month of the postnatal period of ontogenesis, during which - in the first week. In the first week, first and second month of life of ducks, the wall thickness of the rectum increased by 93.1, respectively; 199.5 and $20.4 \%$, the thickness of the mucous membrane - 81.0; 167.1 and 19.5\%, the thickness of the muscular membrane - by 126.1;285.3 and $22.7 \%$, the height of the villi - by 113.2; 208.7 and $7.2 \%$, the width of the villi-by $84.7 ; 70.9$ and $12.5 \%$, their surface area - by 293.8; 427.6 and $20.6 \%$, the depth of the crypt - by 85.1; 49.9 and $52.3 \%$, muscle plate thickness - by 254.0; 750.8 and 15.0\%. The most stable indicators of the rectum during the first year of the postnatal period of ontogenesis were the density of villi and crypts, the number of which after 7 days of age had no significant difference compared to that of a younger age. The indicates of adult birds morphometric parameters of the rectum of ducks corresponded at different ages: in 1-year-old-the thickness of the serous membrane and the density of villi; at 6 months - the diameter of the intestine, the surface area of the villi; at 2 months of age - the thickness of the wall and its mucous membrane, the width of the villi, the depth of the crypt; at 1 month - the thickness of the muscular membrane and plate, the height of the villi, the epithelium of the villi and crypt; at 3 days of age - the density of crypts; at 1 day of age - the width of the crypt.

Key words: ducks, rectum, histological structure, postnatal period of ontogenesis.

\section{Мікроскопічна будова прямої кишки свійської качки}

\author{
Д. С. Махотіна, М. М. Кущ, О. Є. Бондаренко
}

Харківська державна зооветеринарна академія, с. Мала Данилівка Дергачівського району Харківської області, Україна

Метою роботи було визначити особливості мікроскопічної будови прямої кишки качок упродовж першого року постнатального періоду онтогенезу. Для гістологічних досліджень матеріал було відібрано від качок української білогрудої породи 9 вікових груп: 1-, 3-, 7-, 14-, 21-добового, 1-, 2-, 6-місячного і 1-річного віку. Морфометричні параметри мікроструктур встановлювали на поперечних зрізах середньої ділянки кишки. Загальною закономірністю змін морфометричних показників мікроструктур прямої кишки качок було їх збільшення, яке мало асинхронний і нерівномірний характер. У качок 1-3-добового віку продовжувався активний морфогенез кишечнику, про щуо свідчив прочес утворення ворсинок і крипт. Найбільи інтенсивно морфометричні показники 
прямої кишки змінювались у периий місяцьь постнатального періоду онтогенезу, упродовж якого - в перший тиждень. У перший тиждень, перший і другий місяџь життя качок товщчина стінки прямої кишки збільшилась відповідно на 93,1; 199,5 і 20,4 \%, товщина слизової оболонки - на 81,0; 167,1 і 19,5\%, товщина м'язової оболонки - на 126,1; 285,3 і 22,7 \%, висота ворсинок - на 113,2; 208,7 і 7,2 \%, ширина ворсинок - на 84,7; 70,9 і 12,5\%, площқа їхньої поверхні - на 293,8; 427,6 і 20,6 \%, глибина крипт - на 85,1; 49,9 і 52,3 \%, товщина м'язової пластинки - на 254,0; 750,8 і 15,0\%. Найбільш стабільними показниками прямої кишки упродовж першого року постнатального періоду онтогенезу були шільність ворсинок $і$ крипт, кількість яких після 7-добового віку не мала достовірної відмінності порівняно з таким меншого віку. Значенням дорослої птиці морфометричні показники прямої кишки качок відповідали в різному віці: в 1-річному - товщина серозної оболонки і шільність ворсинок; в 6-місячному - діаметр кишки, площа поверхні ворсинок; в 2-місячному вічі - товщина стінки і ї слизової оболонки, ширина ворсинок, глибина крипт; в 1місячному - товщина м'язової оболонки і пластинки, висота ворсинок, епітелію ворсинок $i$ крипт; у 3-добовому віці - щүільність крипт; в 1-добовому віці - ширина крипт.

Ключові слова: качки, пряма кишка, гістологічна будова, постнатальний період онтогенезу.

\section{Вступ}

Як відомо, качки у багатьох країнах є джерелом значної частини всього тваринного білка раціону людини (Yang et al., 2020). На вирощування птиці витрати на корм становлять близько 70 \%, тому підвищення ефективності травлення птицею поживних речовин корму є основним завданням м'ясного птахівництва (Tran et al., 2014; Beauclercq et al., 2018). Ocновним способом зниження цих затрат є оптимізація рецептури раціону і генетичний відбір птиці 3 найефективнішим типом травлення, що базується на знанні біологічних особливостей організму, а саме органів травного апарату (de Verdal et al., 2011; Sell-Kubiak et al., 2017).

Незважаючи на вражаючі успіхи селекції, значні відмінності в інтенсивності росту свійських птахів від їхнії диких попередників, загальні закономірності будови організму сучасних порід і кросів птиці залишились незмінними. Так, незважаючи на значну абсолютну різницю, відносна маса внутрішніх органів пекінської качки і крякви не мала достовірної відмінності (Watkins et al., 2004).

Розвиток апарату травлення - важливий аспект росту молодняку (Katanbaf et al., 1988; Nitsan et al., 1991a). Обсяг шлунково-кишкового тракту є фактором, що обмежує споживання корму і подальший ріст, а також продуктивність дорослої птиці (Nitsan et al., 1991b). Шлунково-кишковий тракт пташенят різних видів сільськогосподарської птиці після вилуплення розвинений не повністю (Krogdahl \& Sell, 1989; Nitsan et al., 1991a; 1991b; Sell et al., 1991; Noy \& Sklan, 1997). Враховуючи, що основні процеси травлення відбуваються в тонкому відділі кишечнику свійських птахів, особливостям його морфофункціональної організації дослідники приділяють більше уваги, ніж товстому (Murakami et al., 2007; Qaisrani et al., 2015). Розвиток травних функцій кишечника в онтогенезі інших видів птахів документовано недостатньо (King et al., 2000), що вказує на актуальність таких досліджень.

Кожний відділ кишечнику демонструє відмінну функцію і фізико-хімічні характеристики, склад мікробіому (Dethlefsen et al., 2007; Rinttilä et al., 2013; Nakao et al., 2015). У товстому відділі кишечнику птахів більш дослідженими є сліпі кишки, враховуючи їх важливу роль в імунному захисті організму, а також у травленні клітковини (Pandit et al., 2018). Пряма кишка птахів залишається поза увагою дослід- ників, і темі іiі будови та функції присвячено лише незначну кількість публікацій. Серед різних видів сільськогосподарської птиці найбільш дослідженою є пряма кишка курчат-бройлерів (Dehkordi \& Ghahremani, 2016).

Через те, що птахи не мають сечового міхура, нирки і товстий відділ кишечнику повинні злагоджено функціонувати з метою підтримання гомеостазу води, електролітів і міжклітинної рідини. Із нирок птахів сечова кислота потрапляє до клоаки й далі в пряму і сліпі кишки, де 3 нею відбуваються певні зміни завдяки мікрофлорі та епітелію слизової оболонки (Braun, 1999; Reyes \& Braun, 2005). У птахів пряма кишка важлива для екскреції іонів Калію, Кальцію, Магнію, всмоктування води й іонів Натрію (активний процес, що стимулює інші абсорбційні функції), хоча цей процес і відбувається менш інтенсивно, ніж у сліпих кишках (Thomas, 1982; van der Klis et al., 1990). Пряма кишка має видові особливості будови. Так, у дикої качки Anas querquedula іiі слизова оболонка утворює поздовжні складки, півмісячні та круглі крипти (Hanafy et al., 2020). Серед інших кишок саме пряма кишка має найбільшу щільність елементів нервової тканини, що вказує на ступінь іiі іннервації. Поздовжній шар м'язової оболонки добре іннервується лише в прямій кишці (Ali \& McLelland, 1978).

Отже, огляд літератури свідчить про важливе значення прямої кишки птахів. Водночас особливості мікроскопічної будови прямої кишки залишаються маловивченими. Інформація про вікові особливості мікроскопічної будови прямої кишки качок в процесі постнатального онтогенезу ми не знайшли, що й обумовило мету роботи.

Мета роботи - визначити особливості морфофункціональної організації прямої кишки качок упродовж першого року постнатального періоду онтогенезу.

\section{Матеріал і методи досліджень}

Для гістологічних досліджень шматочки з середньої ділянки прямої кишки свійських качок (Anas platyrhynchos domesticus) чорної білогрудої породи (n = 5) відбирали від 9 вікових груп: 1-, 3-, 7-, 14-, 21добового, 1-, 2-, 6-місячного та 1-річного віку. Качок добового віку придбали у державній дослідній станції птахівництва НААНУ і утримували як ремонтний молодняк на глибокій підстилці в пташнику ХДЗВА. Під час досліду птиці згодовували стандартний повнораціонний комбікорм згідно з ДСТУ 4120-2002, 
вона мала вільний доступ до води. Профілактичних щеплень і протипаразитарних обробок качкам не проводили. Утримання качок та маніпуляції з ними виконували відповідно до Європейської конвенції про захист хребетних тварин, що використовують для дослідних та інших наукових цілей (Страсбург, 1986).

Отриманий матеріал фіксували у $10 \%$ розчині нейтрального формаліну. Після фіксації у формаліні відібраний матеріал промивали у проточній воді, зневоднювали у спиртах зростаючої концентрації і заливали у парафін за загальноприйнятою методикою. Парафінові гістологічні зрізи забарвлювали гематоксиліном і еозином, а також за Малорі.

Враховуючи, що визначення абсолютної і відносної величини структур організму є одним з головних інструментів, що визначає видові та вікові закономірності росту тварин (Mobini, 2011), у роботі було використано морфометричний метод дослідження.

Морфометричні параметри мікроструктур встановлювали на поперечних зрізах кишки за допомогою окулярної сітки, а також програми Image Tools 3.6. Площу поверхні ворсинок визначали за Iji et al. (2001). Щільність крипт і ворсинок визначали з перерахунком на 1 мм довжини слизової оболонки. Для оцінки вікових змін морфометричних параметрів кишок птиці їх завжди порівнювали з такими меншого віку. Згідно 3 ВНТП-АПК-05.05 до групи молодняку качок зараховують птицю віком від 1 доби до 6 місяців включно, до дорослої птиці - віком понад 6 місяців. Тому для оцінки розвитку окремих мікроструктур кишечнику їх порівнювали з такими качок 1-річного віку.

Оцінку достовірності різниці морфометричних показників виконували за критерієм Ст'юдента

\section{Результати та їх обговорення}

На поперечному зрізі стінки прямої кишки качок 1-3-добового віку виявляли кілька складок слизової оболонки, які містили закладки ворсинок (рис. 1).

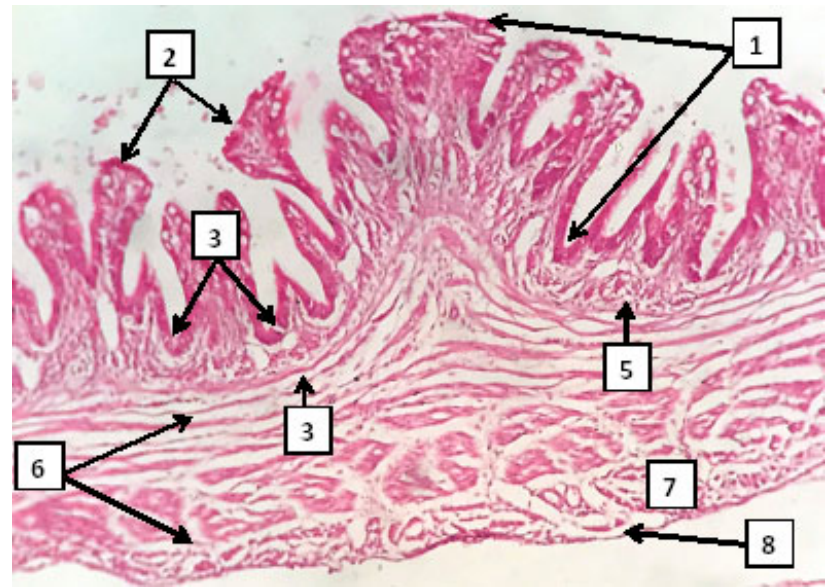

Рис. 1. Пряма кишка качки 1-добового віку. Гістопрепарат. Забарвлення гематоксилін та еозин, х200

Позначення: 1 - закладка складки слизової оболонки; 2 ворсинки; 3 - крипти; 4 - м'язова пластинка слизової оболонки; 5 - нервовий вузол підслизового нервового сплетення; 6 - внутрішній шар м'язової оболонки; 7 - зовнішній шар м'язової оболонки; 8 - серозна оболонка.
У деяких особин у даних вікових групах птиці крипти не виявляли або вони мали вигляд неглибоких заглибин епітелію у власну пластинку слизової оболонки, що свідчить про процеси формоутворення мікроструктур кишечнику.

Основа ворсинок каченят 1-3-добового віку утворена пухкою волокнистою сполучною тканиною, в якій переважала аморфна речовина. У ній виявляли клітини фібробластичного ряду з великими світлими ядрами, лейкоцити, серед яких переважали лімфоцити, тканинні базофіли, а також тонкі колагенові фібрили.

Під дном крипт у вигляді вузької смужки розташована м'язова пластинка, що складалася переважно з одного шару гладких м'язових клітин, що мали поздовжній напрямок (рис. 2).

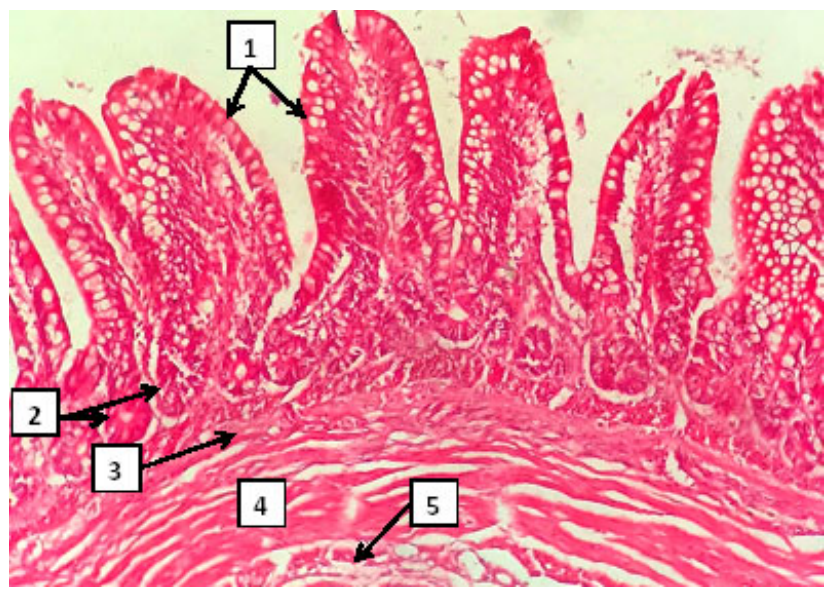

Рис. 2. Пряма кишка качки 3-добового віку. Гістопрепарат. Забарвлення гематоксилін та еозин, $\mathbf{x} 400$

Позначення: 1 - ворсинки; 2 - крипти; 3 - м'язова пластинка слизової оболонки; 4 - внутрішній шар слизової оболонки; 5 - зовнішній шар м'язової оболонки.

Між м'язовою пластинкою слизової оболонки i м'язовою оболонкою, а також в зовнішньому шарі м'язової оболонки виявляли елементи нервових сплетень - нервові вузли і пучки нервових волокон. Нервові вузли підслизового (Мейснера) і м'язової оболонки (міентерального, Ауербаха) сплетення мали переважно овальну форму і чітко виявлялись. До складу нервових вузлів входили кілька тіл нейроцитів мультиполярного типу і нервові волокна (рис. 3).

М'язова оболонка стінки прямої кишки качок 1-добового віку складалась 3 двох шарів: більш товстого внутрішнього $з$ переважно циркулярним напрямком розташування гладких м'язових клітин і менш товстого - зовнішнього, з переважно поздовжнім їх напрямком. Між собою шари м'язової оболонки сполучались тонкими прошарками пухкої волокнистої сполучної тканини.

Серозна оболонка кишки представлена тонкою сполучнотканинною пластинкою, вкритою одношаровим плоским епітелієм - мезотелієм.

Порівняно з качками 1-добового віку, у птиці 314-добового віку в пухкій волокнистій сполучній тканині власної пластинки слизової оболонки, а також між шарами м'язової оболонки був більшим уміст 
колагенових волокон і клітин фібробластичного ряду, тканинних базофілів і лімфоцитів.

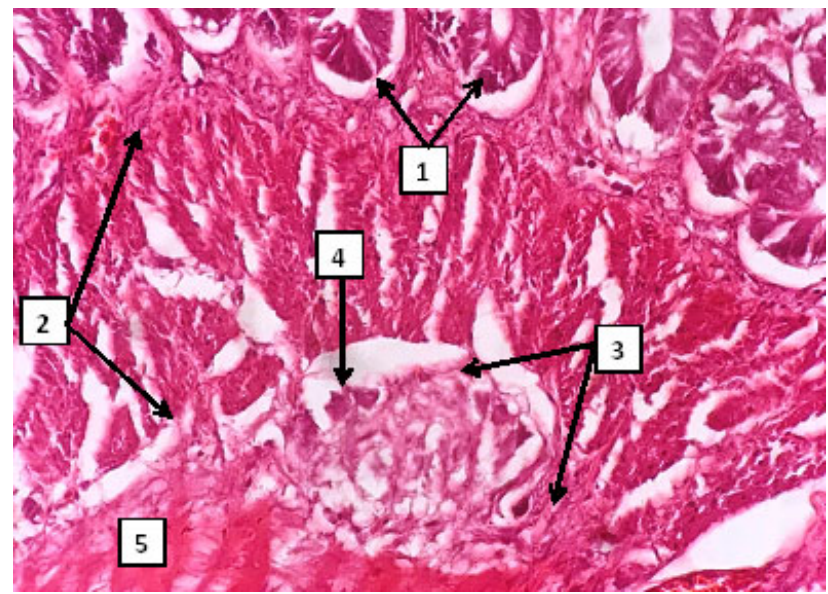

Рис. 3. Пряма кишка качки 14-добового віку. Гістопрепарат. Забарвлення гематоксилін та еозин, х400

Позначення: 1 - крипти; 2 - м'язова пластинка слизової оболонки; 3 - нервовий вузол підслизового нервового сплетення; 4 - мультиполярні нейроцити; 5 - внутрішній шар м'язової оболонки.

Уздовж ворсинок гладкі м'язові клітини розташовувались у вигляді кількох вузьких тяжів. Крім пухкої сполучної тканини, крипти між собою відокремлені вузькими тяжами гладких м'язових клітин. Крім того, такі тяжі у вигляді тонкого поясу оперізували донну частину крипт. Порівняно 3 меншим віком качок у складі власної пластинки в більшій кількості виявляли судини мікроциркуляторного русла, переважно артеріоли і венули.

Діаметр прямої кишки качок збільшувався 3 1-добового віку до 6-місячного віку відповідно 3 $2,38 \pm 0,13$ до $8,13 \pm 0,34$ мкм (табл. 1). Порівняно 3 попереднім, він був більшим у качок 3-, 7-, 21добового, 2- і 6-місячного віку відповідно на 44,5 $(\mathrm{P} \leq 0,01) ; 11,9 ; 33,3(\mathrm{P} \leq 0,05) ; 17,3(\mathrm{P} \leq 0,05)$ i $46,5 \%$ $(\mathrm{P} \leq 0,001)$. У качок 14-добового, 1-місячного i 1-річного віку цей показник був меншим відповідно на 5,7; 2,3 і 14,5\% $(\mathrm{P} \leq 0,05)$.

Товщина стінки прямої кишки качок 1-добового віку становила 352,01 \pm 17,27 мкм. Цей показник збільшувався до 2-місячного віку, був меншим у качок 1річного віку і становив при цьому $1246,10 \pm 47,33$ мкм. Порівняно $з$ меншим віком, у качок 3-, 7-, 14- і 21добового, 1- і 2-місячного віку товщина стінки прямої кишки була більшою відповідно на 52,4 (P $\leq 0,001)$; $26,7 \quad(\mathrm{P} \leq 0,01) ; 12,3 ; 9,7 ; 25,9 \quad(\mathrm{P} \leq 0,01) ; 20,4 \%$ (P $\leq 0,05)$. У качок 1-річного віку цей показник був меншим на $1,9 \%$.

У стінці прямої кишки нами виявлено три оболонки: слизову, м'язову і серозну. У складі слизової оболонки нами виявлено три шари: епітеліальний, власну пластинку і м'язову пластинку (рис. 4). Підслизового шару не встановлено. Наші дані узгоджуються з відповідною інформацією Hodges \& Michael (1975); Kachave et al. (2009), i суперечать даним Khaleel \& Atiea (2017); Dehkordi \& Shakaram (2018); Kadhim et al. (2018), згідно з якою в стінці кишечнику птахів $є$ підслизова основа або вона має слабкий розвиток.

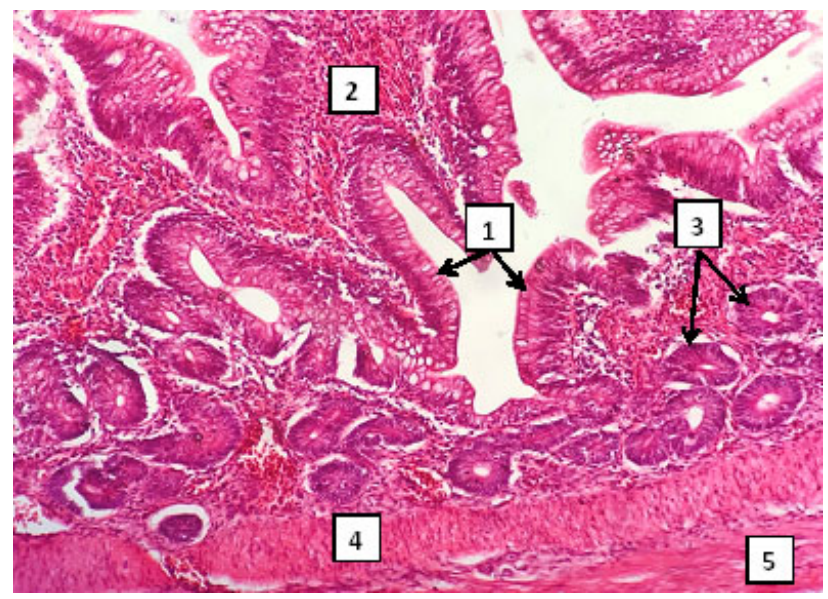

Рис. 4. Пряма кишка качки 1-місячного віку. Гістопрепарат. Забарвлення гематоксилін та еозин, х400 Позначення: 1 - епітелій ворсинок; 2 - пучки гладких м'язових клітин; 3 - крипти; 4 - м'язова пластинка слизової оболонки; 5 - внутрішній шар м'язової оболонки.

Товщина слизової оболонки прямої кишки качок 1-добового віку становила 250,32 \pm 9,47 мкм. 3 віком птиці вона збільшувалась, і в качок 3-, 7-, 14-, 21-добовому, 1-, 2- і 6-місячному віці цей показник був більшим відповідно на 52,4 (P $\leq 0,001) ; 30,9$ $(\mathrm{P} \leq 0,01) ; 10,7 ; 9,4 ; 21,84(\mathrm{P} \leq 0,01) ; 19,5(\mathrm{P} \leq 0,05)$ i 7,8 \%. У 1-річному віці він був меншим на 5,2\%.

Про збільшення товщини слизової оболонки прямої кишки курчат-бройлерів 312 до 44 доби повідомляє Dehkordi \& Shakaram (2018).

Найбільше значення відносної товщини слизової оболонки прямої кишки визначено у качок 1-добового віку, яке становило 71,11 \%. У качок 3-добового 1-річного віку цей показник був меншим і достатньо стабільним, його величину визначали в межах від 62,89 до $67,82 \%$.

Висота ворсинок слизової оболонки прямої кишки качок 1-добового віку становила $170,04 \pm 8,32$ мкм (табл. 2).

3 віком цей показник поступово збільшувався до 6-місячного віку. У птиці 3-, 7- і 14-, 21-добового, 1-, 2- і 6-місячного віку він був більшим відповідно на $49,0 \quad(\mathrm{P} \leq 0,001) ; 43,1 \quad(\mathrm{P} \leq 0,001) ; 5,7 ; 10,9 ; 23,5$ $(\mathrm{P} \leq 0,05) ; 7,2$ і 8,0 \%. У качок 1-річного віку висота ворсинок була меншою на 5,1\%.

Середній віковий показник висоти ворсинок прямої кишки становив 429,69 $\pm 50,76$ мкм, сліпих кишок - 258,4 \pm 39,41 мкм. Отримані нами дані суперечать інформації Krygin (1960) щодо меншої висоти ворсинок у прямій кишці качок порівняно зі сліпими.

Ширина ворсинок у качок 1-добового віку становила 74,31 \pm 3,33 мкм. У старшої птиці вона була більшою: у качок 3-, 7-, 14-добового, 1-, 2- і 6місячного віку відповідно на 38,9 ( $\mathrm{P} \leq 0,001)$; 33,0 (P $\leq 0,001) ; 8,1 ; 12,5$ і 15,6 \%. У птиці 21-добового і 1-річного віку цей показник був меншим за такий попереднього віку відповідно на 3,9 і 1,0 \%. 


\section{Таблиця 1}

Морфометричні показники стінки прямої кишки качок чорної білогрудої породи 1-добового - 1-річного віку, $\mathrm{M} \pm \mathrm{m}, \mathrm{n}=5$

\begin{tabular}{|c|c|c|c|c|c|c|}
\hline Вік & $\begin{array}{c}\text { Діаметр } \\
\text { кишки, мм }\end{array}$ & $\begin{array}{c}\text { Товщина стінки } \\
\text { кишки, мкм }\end{array}$ & $\begin{array}{c}\text { Товщина слизової } \\
\text { оболонки, мкм }\end{array}$ & $\begin{array}{c}\text { Відносна } \\
\text { товщина слизової } \\
\text { оболонки, \% }\end{array}$ & $\begin{array}{c}\text { Товщина м’язової } \\
\text { оболонки, мкм }\end{array}$ & $\begin{array}{c}\text { Товщина сероз- } \\
\text { ної оболонки, } \\
\text { мкм }\end{array}$ \\
\hline 1 доба & $2,38 \pm 0,13$ & $352,01 \pm 17,27$ & $250,32 \pm 9,47$ & 71,11 & $97,97 \pm 4,87$ & $3,72 \pm 0,14$ \\
\hline 3 доби & $3,44 \pm 0,18^{* *}$ & $536,35 \pm 21,82 * * *$ & $346,12 \pm 13,95 * * *$ & 64,53 & $184,38 \pm 8,94 * * *$ & $5,85 \pm 0,18 * * *$ \\
\hline 7 діб & $3,85 \pm 0,21$ & $679,81 \pm 24,96^{* *}$ & $453,00 \pm 20,87 * *$ & 66,64 & $221,47 \pm 9,88^{*}$ & $5,34 \pm 0,19$ \\
\hline 14 діб & $3,63 \pm 0,23$ & $763,24 \pm 32,47$ & $501,54 \pm 20,94$ & 65,71 & $255,00 \pm 12,33$ & $6,70 \pm 0,27 * *$ \\
\hline 21 доба & $4,84 \pm 0,28^{*}$ & $837,10 \pm 40,80$ & $548,80 \pm 22,55$ & 65,56 & $280,49 \pm 13,02$ & $7,81 \pm 0,26^{*}$ \\
\hline 1 мiс. & $4,73 \pm 0,21$ & $1054,10 \pm 42,92 * *$ & $668,63 \pm 24,93 * *$ & 64,43 & $377,50 \pm 18,44 * *$ & $7,94 \pm 0,27$ \\
\hline 2 мiс. & $5,55 \pm 0,20^{*}$ & $1269,31 \pm 51,84^{*}$ & $798,88 \pm 37,31 *$ & 62,89 & $463,22 \pm 20,40 *$ & $8,22 \pm 0,33$ \\
\hline 6 мiс. & $8,13 \pm 0,34 * * *$ & $1270,30 \pm 47,93$ & $861,57 \pm 38,30$ & 67,82 & $400,75 \pm 14,97$ & $8,02 \pm 0,40$ \\
\hline $1 \mathrm{p}$. & $6,95 \pm 0,30 *$ & $1246,10 \pm 47,33$ & $816,64 \pm 32,52$ & 65,54 & $418,94 \pm 18,86$ & $10,53 \pm 0,44 * *$ \\
\hline
\end{tabular}

Примітка: *-P $\leq 0,05 ; * *-\mathrm{P} \leq 0,01 ; * * *-\mathrm{P} \leq 0,001$ порівняно 3 попереднім віком

Таблиця 2

Мікроскопічні показники ворсинок прямої кишки качок чорної білогрудої породи 1-добового - 1-річного віку, $\mathrm{M} \pm \mathrm{m}, \mathrm{n}=5$

\begin{tabular}{|c|c|c|c|c|c|}
\hline Вік & Щільність, на 1 мм & Висота, мкм & Ширина, мкм & $\begin{array}{c}\text { Площа поверхні, } \\
\times 10^{3}, \text { мкм }^{2}\end{array}$ & $\begin{array}{c}\text { Висота епітелію, } \\
\text { мкм }\end{array}$ \\
\hline 1 доба & $13,13 \pm 0,45$ & $170,04 \pm 8,32$ & $74,31 \pm 3,33$ & $12,64 \pm 0,54$ & $14,37 \pm 0,67$ \\
\hline 3 доби & $7,63 \pm 0,24 * * *$ & $253,30 \pm 10,34 * * *$ & $103,22 \pm 4,29 * * *$ & $26,15 \pm 0,87 * * *$ & $20,20 \pm 0,88 * * *$ \\
\hline 7 діб & $6,88 \pm 0,22 *$ & $362,52 \pm 14,33 * * *$ & $137,30 \pm 5,21 * * *$ & $49,77 \pm 1,44 * * *$ & $18,34 \pm 0,37$ \\
\hline 14 діб & $6,44 \pm 0,22$ & $383,34 \pm 15,94$ & $122,34 \pm 4,30$ & $46,90 \pm 1,38$ & $24,52 \pm 0,77 * * *$ \\
\hline 21 доба & $6,63 \pm 0,19$ & $425,05 \pm 19,37$ & $117,52 \pm 3,84$ & $49,95 \pm 1,35$ & $22,80 \pm 1,54$ \\
\hline 1 мiс. & $6,51 \pm 0,21$ & $524,98 \pm 23,88^{*}$ & $127,03 \pm 6,11$ & $66,69 \pm 2,27 * * *$ & $30,01 \pm 1,22 * *$ \\
\hline 2 мiс. & $6,25 \pm 0,14$ & $562,63 \pm 27,90$ & $142,95 \pm 6,94$ & $80,43 \pm 3,95^{*}$ & $29,45 \pm 1,37$ \\
\hline 6 мiс. & $6,50 \pm 0,14$ & $607,50 \pm 26,39$ & $165,20 \pm 7,55$ & $98,54 \pm 4,11 *$ & $30,04 \pm 1,06$ \\
\hline $1 \mathrm{p}$. & $5,63 \pm 0,12 * *$ & $577,86 \pm 21,07$ & $163,47 \pm 6,22$ & $94,46 \pm 3,87$ & $28,11 \pm 1,22$ \\
\hline
\end{tabular}

Примітка: $*-\mathrm{P} \leq 0,05 ; * *-\mathrm{P} \leq 0,01 ; * * *-\mathrm{P} \leq 0,001$ порівняно 3 попереднім віком

Висота епітелію ворсинок найменше значення мала в качок 1-добового віку і становила $14,37 \pm 0,67$ мкм. У старшої птиці вона збільшувалась. Порівняно 3 птицею меншого віку, в 3-, 14-добовому, 1- і 6-місячному віці вона була більшою відповідно на 40,6 (Р $\leq 0,001)$; $33,7$ ( $\mathrm{P} \leq 0,001) ; 31,6(\mathrm{P} \leq 0,01) ; 2,0 \%$. У качок 7- i 21-добового, 2-місячного і 1-річного віку цей показник був меншим відповідно на 9,2; 7,0; 1,9 і 6,4 \%.

Площа поверхні ворсинок прямої кишки качок 1 -добового віку становила $12,64 \pm 0,54 \times 10^{3}$ мкм $^{2}$. У птиці 3-, 7-, 21-добового, 1-, 2- і 6-місячного віку цей показник був більшим за такий качок меншого віку відповідно на 106,9 (P $\leq 0,001)$; 90,3 (P $\leq 0,001) ; 6,5$; $33,5(\mathrm{P} \leq 0,001) ; 20,6(\mathrm{P} \leq 0,05)$ i $22,5 \%(\mathrm{P} \leq 0,05)$. $\mathrm{Y}$ качок 14-добового і 1-річного віку площа поверхні ворсинок була меншою, ніж у попереднього віку, відповідно на 5,8 і 4,1\%.

Щільність ворсинок прямої кишки качок 1 -добового віку становила $13,13 \pm 0,45$ на 1 мм слизової оболонки. Найбільш суттєво цей показник зменшився 3 1-добового до 3-добового віку птиці - на 41,9\%. У качок 7-добового - 6-місячного віку значення щільності ворсинок визначали в межах вузького “коридору” від 6,25 $\pm 0,14$ до $6,88 \pm 0,22$. У качок 1-річного віку цей показник порівняно з таким молодшого віку був меншим на $13,4 \%$.

У качок 1-добового віку глибина крипт прямої кишки становила 74,85 \pm 3,01 мкм (табл. 3). У старшої птиці цей показник збільшувався до 6-місячного віку, досягаючи максимального значення, яке становило 205,30 \pm 4,39 мкм. Порівняно з попереднім, у птиці 3-, 14-, 21-добового, 1-, 2- і 6-місячного віку глибина крипт була більшою відповідно на 10,$2 ; 26,7$ $(\mathrm{P} \leq 0,05) ; 2,4 ; 5,4 ; 87,9(\mathrm{P} \leq 0,001)$ i $12,1 \%(\mathrm{P} \leq 0,05)$. $\mathrm{У}$ качок 7-добового і 1-річного віку цей показник був меншим за такий молодшої птиці відповідно на 13,6 $(\mathrm{P} \leq 0,05)$ i $8,2 \%$.

На відміну від ворсинок, щільність яких 3 1- i 3-добового віку відповідно до 3- і 7- добового достовірно зменшилась, щільність крипт з 1- до 3-добового віку качок збільшилась на 23,9 \% (P $\leq 0,001)$. У птиці 7-добового віку і старшої цей показник упродовж всього періоду спостереження не мав достовірної відмінності між собою і перебував у межах вузького “коридору значень” від 15,25 \pm 0,20 до 18,71 \pm 0,31 на 1 мм слизової оболонки.

Ширину крипт упродовж всього вікового періоду визначали в межах від 45,61 $\pm 1,74$ до 52,13 $\pm 1,67$ мкм. Іїі значення достовірної різниці між собою не мали.

Висота епітеліального шару крипт прямої кишки найменше значення мала у качок 1-добового віку $\mathrm{i}$ становила $12,33 \pm 0,41$ мкм. Надалі вона збільшувалась, сягаючи максимального значення - 22,82 $\pm 1,27$ мкм у птиці 6-місячного віку (рис. 5). Порівняно з попереднім віком, цей показник був більшим у качок 3-, 7-, 21-добового, 1- і 6-місячного віку відповідно на 14,1 
$(\mathrm{P} \leq 0,05) ; 8,7(\mathrm{P} \leq 0,05) ; 8,3(\mathrm{P} \leq 0,05) ; 35,6(\mathrm{P} \leq 0,05)$ $10,5 \%$. У птиці 14-добового, 2-місячного і 1-річного віку він був меншим відповідно на 3,0; 5,4 і 15,0\%.
Товщина м’язової пластинки слизової оболонки прямої кишки найменшою була в качок 1-добового віку і становила 5,43 $\pm 0,12$ мкм (табл. 4).

\section{Таблиця 3}

Мікроскопічні показники крипт прямої кишки качок чорної білогрудої породи 1-добового - 1-річного віку, $\mathrm{M} \pm \mathrm{m}, \mathrm{n}=5$

\begin{tabular}{lclcc}
\hline \multicolumn{1}{c}{ Вік } & Щільність, на 1 мм & Глибина, мкм & Ширина, мкм & Висота епітелію, мкм \\
\hline 1 доба & $15,13 \pm 0,54$ & $74,85 \pm 3,01$ & $51,25 \pm 2,02$ & $12,33 \pm 0,41$ \\
3 доби & $18,75 \pm 0,48^{* * *}$ & $82,52 \pm 3,44$ & $46,03 \pm 1,88$ & $14,07 \pm 0,37^{*}$ \\
7 діб & $17,50 \pm 0,52$ & $71,26 \pm 2,87^{*}$ & $45,61 \pm 1,74$ & $15,30 \pm 0,30^{*}$ \\
14 діб & $18,71 \pm 0,31$ & $90,32 \pm 3,51^{* *}$ & $50,37 \pm 2,07$ & $14,87 \pm 0,28$ \\
21 доба & $18,26 \pm 0,30$ & $92,50 \pm 3,08$ & $48,68 \pm 1,61$ & $16,11 \pm 0,33^{*}$ \\
1 міс. & $18,52 \pm 0,28$ & $97,45 \pm 2,44$ & $46,40 \pm 1,20$ & $21,85 \pm 0,43 *$ \\
2 міс. & $16,34 \pm 0,24$ & $183,11 \pm 5,54^{* * *}$ & $48,75 \pm 1,47$ & $20,66 \pm 0,58$ \\
6 міс. & $15,25 \pm 0,20$ & $205,30 \pm 4,39^{*}$ & $52,13 \pm 1,67$ & $22,82 \pm 1,27$ \\
1 р. & $17,52 \pm 0,24$ & $188,55 \pm 5,72$ & $47,50 \pm 1,24$ & $19,40 \pm 0,79$ \\
\hline
\end{tabular}

Примітка: $*-\mathrm{P} \leq 0,05 ; * *-\mathrm{P} \leq 0,01 ; * * *-\mathrm{P} \leq 0,001$ порівняно 3 попереднім віком

\section{Таблиця 4}

Мікроскопічні показники м'язової оболонки (МО) і м'язової пластинки прямої кишки качок чорної білогрудої породи 1-добового - 1-річного віку, $\mathrm{M} \pm \mathrm{m}, \mathrm{n}=5$

\begin{tabular}{|c|c|c|c|c|c|c|}
\hline Вік & $\begin{array}{c}\text { Товщина МO, } \\
\text { мкм }\end{array}$ & $\begin{array}{c}\text { Відносна } \\
\text { товщина } \mathrm{MO}, \\
\%\end{array}$ & $\begin{array}{c}\text { Товщина } \\
\text { внутрішнього шару } \\
\text { МО, мкм }\end{array}$ & $\begin{array}{c}\text { Товщина } \\
\text { зовнішнього } \\
\text { шару МО, мкм }\end{array}$ & $\begin{array}{c}\text { Відносна товщи- } \\
\text { на внутрішнього } \\
\text { шару МО, \% }\end{array}$ & $\begin{array}{c}\text { Товщина } \\
\text { м’язової плас- } \\
\text { тинки, мкм }\end{array}$ \\
\hline 1 доба & $97,97 \pm 4,87$ & 27,83 & $83,34 \pm 4,31$ & $14,63 \pm 0,55$ & 85,07 & $5,43 \pm 0,12$ \\
\hline 3 доби & $184,38 \pm 8,94 * * *$ & 34,38 & $153,13 \pm 6,84 * * *$ & $31,25 \pm 0,97 * * *$ & 83,05 & $10,30 \pm 0,17 * * *$ \\
\hline 7 діб & $221,47 \pm 9,88^{*}$ & 32,58 & $191,25 \pm 7,33 * *$ & $30,22 \pm 1,24$ & 86,35 & $19,22 \pm 0,51 * * *$ \\
\hline 14 діб & $255,00 \pm 12,33$ & 33,41 & $231,25 \pm 8,07 * *$ & $23,75 \pm 0,97 * *$ & 90,69 & $27,88 \pm 0,77$ \\
\hline 21 доба & $280,49 \pm 13,02$ & 33,51 & $255,84 \pm 11,39$ & $24,65 \pm 0,87$ & 91,21 & $31,25 \pm 1,26^{*}$ \\
\hline 1 міс. & $377,50 \pm 18,44 * *$ & 35,81 & $341,25 \pm 12,80 * *$ & $36,25 \pm 1,12 * * *$ & 90,40 & $46,20 \pm 1,30 * * *$ \\
\hline 2 міс. & $463,22 \pm 20,40^{*}$ & 36,47 & $420,66 \pm 18,95 * *$ & $42,56 \pm 1,89 *$ & 90,81 & $53,14 \pm 2,41$ \\
\hline 6 міс. & $400,75 \pm 14,97^{*}$ & 31,55 & $362,50 \pm 14,33^{*}$ & $38,25 \pm 2,11$ & 90,46 & $48,77 \pm 1,22$ \\
\hline $1 \mathrm{p}$. & $418,94 \pm 18,86$ & 33,62 & $385,42 \pm 12,21$ & $33,52 \pm 2,27$ & 92,00 & $50,23 \pm 1,34$ \\
\hline
\end{tabular}

Примітка: *-P $\leq 0,05 ; * *-\mathrm{P} \leq 0,01 ; * * *-\mathrm{P} \leq 0,001$ порівняно 3 попереднім віком

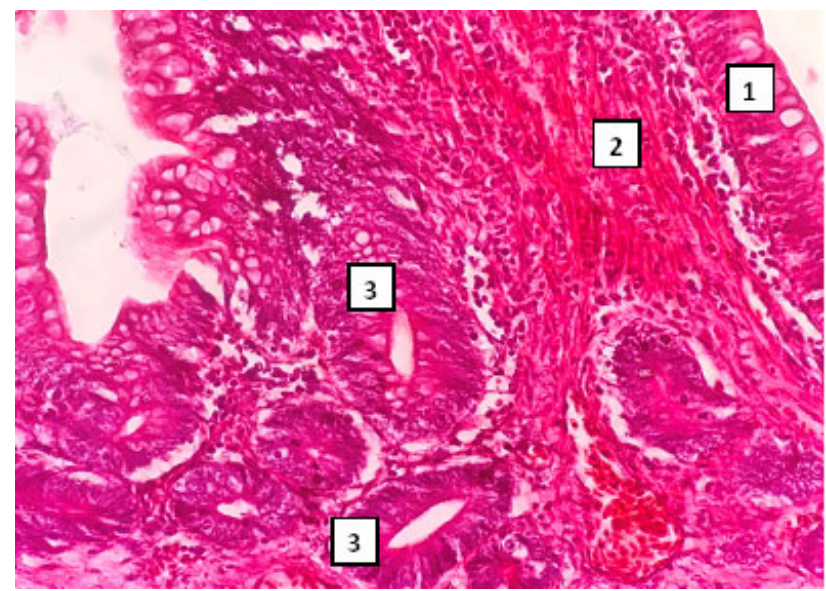

Рис. 5. Пряма кишка качки 6-місячного віку. Гістопрепарат. Забарвлення: гематоксилін та еозин, х400

Позначення: 1 - епітелій ворсинки; 2 - пучки гладких м'язових клітин; 3 - крипти.

У старшої птиці до 2-місячного віку цей показник збільшувався. Порівняно з меншим віком, у качок 3-, 7-, 14-, 21-добового, 1- і 2-місячного і 1-річного віку він був більшим відповідно на 89,7 (P $\leq 0,001)$; 86,6 $(\mathrm{P} \leq 0,001) ; 45,1(\mathrm{P} \leq 0,001) ; 12,1 ; 47,8(\mathrm{P} \leq 0,001) ; 15,0$ $(\mathrm{P} \leq 0,05)$ i 3,0\% (рис. 6).

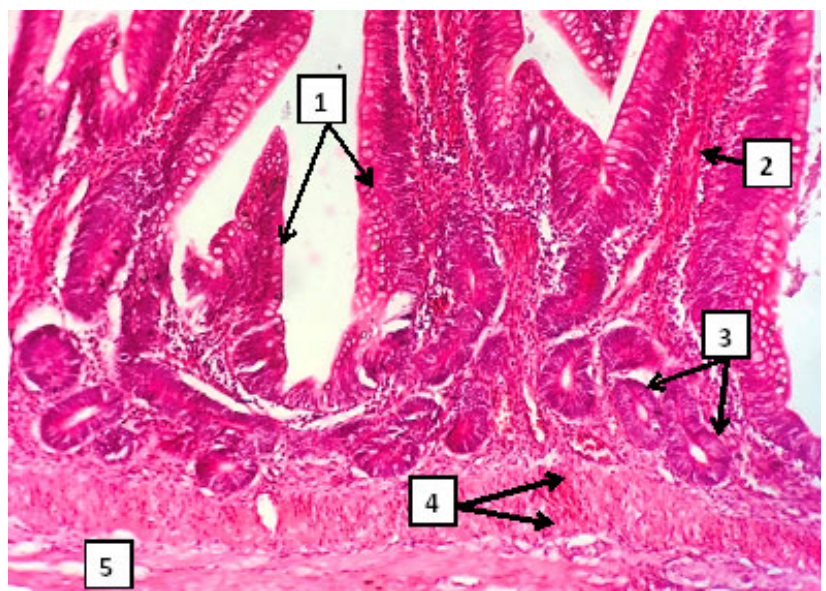

Рис. 6. Пряма кишка качки 1-річного віку. Гістопрепарат. Забарвлення гематоксилін та еозин, х400

Позначення: 1 - епітелій ворсинок; 2 - пучки гладких м'язових клітин; 3 - крипти; 4 - м'язова пластинка слизової оболонки; 5 - внутрішній шар м'язової оболонки.

У качок 6-місячного віку товщина м'язової пластинки слизової оболонки була меншою на 8,2 \%.

Товщина м'язової оболонки прямої кишки качок 1-добового віку становила 97,97 \pm 4,87 мкм. До 2-місячного віку іiі величина збільшувалась і сягала 
при цьому найбільшого значення, яке становило $463,22 \pm 20,40$ мкм. Порівняно 3 попереднім у качок 3-, 7-, 14- , 21-добового, 1- і 2-місячного і 1-річного віку вона була більшою відповідно на 88,2 (P $\leq 0,001)$; $20,1(\mathrm{P} \leq 0,05) ; 15,1 ; 10,0 ; 34,6(\mathrm{P} \leq 0,01) ; 22,7(\mathrm{P} \leq$ $0,05)$ і $4,5 \%$. У качок 6-місячного віку цей показник був меншим за такий птиці молодшого віку на 13,5 \% $(\mathrm{P} \leq 0,05)$. Відносна товщина м'язової оболонки прямої кишки найбільш суттєвих змін зазнала 3 1- до 3-добового віку, коли вона збільшилась 3 27,83 до 34,38 \%. Надалі - до 1-річного віку качок іiі значення визначали в межах від 31,55 до 36,47 \%.

Відносну товщину внутрішнього шару м'язової оболонки прямої кишки в качок 1-7-добового віку визначали в межах 83,05-86,35 \%. У старшої птиці цей показник був більшим - від 90,40 до 92,00\%. Отже, загальною закономірністю динаміки товщини шарів м'язової оболонки було збільшення внутрішнього шару і відповідно - зменшення зовнішнього. Наші дані узгоджуються 3 (Zharova \& Tkachev, 2007), які вказують на більш товстий внутрішній шар м'язової оболонки кишечнику свійських видів птиці.

Абсолютна товщина серозної оболонки прямої кишки качок з віком збільшувалась з $3,72 \pm 0,14$ мкм в 1-добовому віці до 10,53 \pm 0,44 мкм у 1-річному. Її відносна товщина у качок 1-добового віку становила $1,06 \%, 1$-річного - 0,84\%.

Отже, загальною закономірністю змін переважної більшості параметрів морфологічних структур товстого відділу кишечнику качок упродовж першого року постнатального періоду онтогенезу було їх збільшення. В один і той же віковий період спостерігали збільшення величини одних структур і зменшення інших. Періоди збільшення чергувались 3 такими зменшення. Про зменшення з віком величини мікроструктур кишечнику в молодняку домашньої птиці повідомляють Trifonov \& Kuleshov (2008).

Як свідчать дані інших дослідників, асинхронність розвитку структур кишечнику $є$ його характерною особливістю (Sell et al., 1991; Liu \& Oberg, 2010).

Про найбільш інтенсивний характер росту мікроструктур кишечнику на ранніх етапах постнатального періоду онтогенезу свійської птиці повідомляють Noy \& Sklan (1997); Sklan (2001).

Найбільш інтенсивно більшість морфометричних показників прямої кишки збільшувалась у перший місяць постнатального онтогенезу качок, менш - у другий. У перший місяць найбільш інтенсивно вони збільшувались у перший тиждень. У перший тиждень, перший і другий місяць життя качок товщина стінки прямої кишки збільшилась відповідно на 93,1 $(\mathrm{P} \leq 0,001) ; 199,5(\mathrm{P} \leq 0,001)$ i $20,4 \%(\mathrm{P} \leq 0,05)$, товщина слизової оболонки - на 81,0 (P $\leq 0,001) ; 167,1$ $(\mathrm{P} \leq 0,001)$ і $19,5 \%(\mathrm{P} \leq 0,05)$, товщина м'язової оболонки - на $126,1(\mathrm{P} \leq 0,001) ; 285,3(\mathrm{P} \leq 0,001)$ і $22,7 \%$ (P $\leq 0,05)$, висота ворсинок - на 113,2 (P $\leq 0,001)$; $208,7(\mathrm{P} \leq 0,001)$ і 7,2 \%, ширина ворсинок - на 84,7 $(\mathrm{P} \leq 0,001) ; 70,9(\mathrm{P} \leq 0,001)$ i $12,5 \%$, площа їх поверхні - на 293,8 (P $\leq 0,001) ; 427,6(\mathrm{P} \leq 0,001)$ і $20,6 \%$ $(\mathrm{P} \leq 0,05)$, глибина крипт - на 85,1 (P $\leq 0,001) ; 49,9$ $(\mathrm{P} \leq 0,001)$ i $52,3 \%$ \% $(\mathrm{P} \leq 0,001)$, товщина м'язової пла- стинки - на 254,0 (P $\leq 0,001) ; 750,8(\mathrm{P} \leq 0,001)$ і 15,0 \% $(\mathrm{P} \leq 0,05)$.

Як відомо, збільшення маси органів травлення має алометричний характер, тобто, вона збільшуються швидше, ніж маса всього тіла. Їх відносні показники $\epsilon$ максимальними у 6-8-добовому віці в індиків (Sell et al., 1991; Noy \& Sklan, 1998), у віці від 6 до 10 діб - у курчат (Katanbaf et al., 1988). Отримані нами дані узгоджуються 3 інформацією інших дослідників (Moran, 1985; Uni et al., 1999; Sklan \& Noy, 2000; Yovchev et al., 2013) стосовно найбільш інтенсивного характеру збільшення мікроструктур кишечнику сільськогосподарської птиці у перші 2 тижні життя.

\section{Висновки}

1. Загальною закономірністю динаміки більшості морфометричних параметрів прямої кишки качок упродовж 1-добового - 1-річного віку було збільшення 3 віком. Зміни показників величини мікроструктур мали асинхронний i нерівномірний характер.

2. Значенням дорослої птиці морфометричні показники прямої кишки качок відповідали в різному віці: в 1-річному - товщина серозної оболонки, щільність ворсинок; в 6-місячному - діаметр кишки, площа поверхні ворсинок; в 2-місячному віці товщина стінки і іiі слизової оболонки, ширина ворсинок, глибина крипт; в 1-місячному - товщина м'язової оболонки і пластинки, висота ворсинок, епітелію ворсинок і крипт; у 3-добовому віці щільність крипт; в 1-добовому віці - ширина крипт.

3. Найбільш інтенсивно морфометричні показники прямої кишки змінювались у перший місяць постнатального періоду онтогенезу, упродовж якого - у перший тиждень.

\section{References}

Ali, H. A., \& McLelland, J. (1978). Avian enteric nerve plexuses. A histochemical study. Cell and Tissue Research, 189(3), 537-548. doi: 10.1007/BF00209139.

Beauclercq, S., Nadal-Desbarats, L., Hennequet-Antier, C., Gabriel, I., Tesseraud, S., Calenge, F., Le BihanDuval, E., \& Mignon-Grasteau, S. (2018). Relationships between digestive efficiency and metabolomic profiles of serum and intestinal contents in chickens. Scientific Reports, 8(1), 66-78. doi: 10.1038/s41598018-24978-9.

Braun, E. J. (1999). Integration of renal and gastrointestinal function. Journal of Experimental Zoology, 283(45), 495-499. doi: 10.1002/(sici)1097010x(19990301/01)283:4/5<495::aid-jez20>3.0.co;2-.

de Verdal, H., Narcy, A., Bastianelli, D., Chapuis, H., Même, N., Urvoix, S., Le Bihan-Duval, E., \& Mignon-Grasteau, S. (2011). Improving the efficiency of feed utilization in poultry by selection. 1. Genetic parameters of anatomy of the gastro-intestinal tract and digestive efficiency. BMC Genetics, 12(59). doi: 10.1186/1471-2156-12-59. 
Dehkordi, R. A. F., \& Ghahremani, P. (2016). Developmental study of rectum in broiler chicken: A stereological and morphometrical study. Veterinary Research Forum, 7(1), 41-45. URL: https://www.ncbi.nlm.nih.gov/ pmc/articles/PMC4867036.

Dehkordi, R. A. F., \& Shakaram, M. (2018). Morphology of rectum in broiler chicken and domestic fowl: notability of retrograde peristalsis for water preservation. Journal of Applied Animal Research, 46(1), 599-603. doi: 10.1080/09712119.2017.1367687.

Dethlefsen, L., McFall-Ngai, M., \& Relman, D. A. (2007). An ecological and evolutionary perspective on human-microbe mutualism and disease. Nature, 449, 811-818. doi: 10.1038/nature06245.

Hanafy, B. G., Abumandour, M. M. A., \& Bassuoni, N. F. (2020). Morphological features of the gastrointestinal tract of Garganey (Anas querquedula, Linnaeus 1758) Oesophagus to coprodeum. Anatomia, Histologia, Embryologia, 49(2), 233-250. doi: 10.1111/ahe.12519.

Hodges, R. D., \& Michael, E. (1975). Structure and histichemistry of the normal intestine of the fowl. The Fine structure of the Duodenal Crypt. Cell and Tissue Research, 160, 125-138. doi: 10.1007/BF00219846.

Iji, P. A., Saki, A., \& Tivey, D. R. (2001). Body and intestinal growth of broiler chickens on a commercial starter diet. 1. Intestinal weight and mucosal development. British Poultry Science, 42, 505-513. doi: 10.1080/00071660120073151.

Kachave, C. D., Bhosle, N. S., Mamde, C. S., \& Lambate, S. B. (2009). Histological observations on small intestine in broiler and layer of poultry birds. Royal Veterinary Journal of India, 5(1-2), 5-9.

Kadhim, A. B., Dali, E. I., Sharoot, H. A., \& Abdul-Rida, M. A.-H. (2018). Histomorphological study of duodenum of goose (Anser anser). Al-Qadisiyah Journal of Veterinary Medicine Sciences, 17(2), 43-48. doi: 10.29079/vol17iss2art503.

Katanbaf, M. N., Dunnington, E. A., \& Siegel, P. B. (1988). Allomorphic relationships from hatching to 56 days in parental lines and F1 crosses of chickens selected for high or low body weight. Growth Development and Aging, 52, 11-22.

Khaleel, I. M., \& Atiea, G. D. (2017). Morphological and histochemical study of small intestine inindigenous ducks (Anas platyrhynchos). IOSR Journal of Agriculture and Veterinary Science (IOSR-JAVS), 10(7), 1927. doi: 10.9790/2380-1007021927.

King, D., Asem, E., \& Adeola, O. (2000). Ontogenetic development of intestinal digestive functions in White Pekin ducks. The Journal of Nutrition, 130(1), 57-62. doi: 10.1093/JN/130.1.57.

Krogdahl, A., \& Sell, J. L. (1989). Influence of age on lipase, amylase and protease activities in pancreatic tissue and intestinal contents of young turkeys. Poultry Science, 68, 1561-1568. doi: 10.3382/ps.0681561.

Krygin, A. V. (1960). Sravnitelnaya morfologiya pichshevaritelnogo apparata domashnih ptiz. Materialy nauchnoi konferencii. Troisk, 183-199 (in Russian).

Liu, E. H., \& Oberg, K. (2010). The history and development of the gastroenteropancreatic endocrine axis. En- docrinology and Metabolism Clinics of North America, 39(4), 697-711. doi: 10.1016/j.ecl.2010.09.002.

Mobini, B. (2011). Age-dependent morphometric changes of different parts of small and large intestines in the Ross broilers. International Journal for Agro Veterinary and Medical Sciences, 5, 456-463.

Moran, E. T. (1985). Digestion and absorption of carbohydrates in fowl and events through perinatal development. The Journal of Nutrition, 115, 665-674. doi: 10.1093/jn/115.5.665.

Murakami, A. E., Sakamoto, M. I., Natali, M. R. M., Souza, L. M. G., \& Franco, J. R. G. (2007). Supplementation of glutamine and vitamin e on the morphometry of the intestinal mucosa in broiler chickens. Poultry Science, 86(3), 488-495. doi: $10.1093 / \mathrm{ps} / 86.3 .488$.

Nakao, N., Kaneda, H., Tsushima, N., Ohta, Y., \& Tanaka, M. (2015). Characterization of primary structure and tissue expression profile of the chicken apical sodium-dependent bile acid transporter mRNA. Poultry Science, 94, 722-727 doi: 10.3382/ps/pev027.

Nitsan, Z., Avraham, G. B. Zorfe, Z., \& Nir, I. (1991b). Growth and development of the digestive organs and some enzymes in the broiler chicks after hatching. British Poultry Science, 32, 515-523. doi: 10.1080/00071669108417376.

Nitsan, Z., Duntington, E. A., \& Siegel, P. B. (1991a). Organ growth and digestive enzyme levels to fifteen days of age in lines of chickens differing in body weight. Poultry Science, 70, 2040-2048. doi: $10.3382 /$ ps.0702040.

Noy, Y., \& Sklan, D. (1997). Posthatch development in poultry. Journal of Applied Poultry Research, 6, 344354. doi: 10.1093/japr/6.3.344.

Noy, Y., \& Sklan, D. (1998). Yolk utilization in the newly hatched poultry. British Poultry Science, 37, 987996. doi: 10.1080/00071669889042.

Pandit, K., Dhote, B. S., Mahanta, D., Sathapathy, S., Tamilselvan, S., Mrigesh, M., \& Mishra, S. (2018). Histological, histomorphometrical and histochemical studies on the large intestine of Uttara fowl. International Journal of Current Microbiology and Applied Sciences, 7(3), 1477-1491. doi: 10.20546/ijcmas.2018.703.176.

Qaisrani, S. N., van Krimpen, M. M., Kwakkel, R. P., Verstegen, M. W. A., \& Hendriks, W. H. (2015). Diet structure, butyric acid, and fermentable carbohydrates influence growth performance, gut morphology, and cecal fermentation characteristics in broilers. Poultry Science, 94(9), 2152-2164. doi: 10.3382/ps/pev003.

Reyes, L., \& Braun, E. J. (2005). The functional morphology of the english sparrow cecum. Comparative Biochemistry and Physiology - Part A: Molecular \& Integrative Physiology, 141(3), 292-297. doi: 10.1016/j.cbpb.2005.05.053.

Rinttilä, T., \& Apajalahti, J. (2013). Intestinal microbiota and metabolites-Implications for broiler chicken health and performance. Journal of Applied Poultry Research, 22, 647-658. doi: 10.3382/japr.2013-00742.

Sell, J. L., Angel, C. R., Piquer, F. J., Mallarino, E. G., \& Al-Batshan, H. A. (1991). Developmental patterns of selected characteristics of the gastrointestinal tract of 
young turkeys. Poultry Science, 70, 1200-1205. doi: $10.3382 /$ ps.0701200.

Sell-Kubiak, E., Wimmers, K., Reyer, H., \& Szwaczkowski, T. (2017). Genetic aspects of feed efficiency and reduction of environmental footprint in broilers: a review. Journal of Applied Genetics, 58(4), 487-498. doi: $10.1007 / \mathrm{s} 13353-017-0392-7$.

Sklan, D. (2001). Development of the digestive tract of poultry. British Poultry Science, 57, 415-428. doi: 10.1079/WPS20010030.

Sklan, D., \& Noy, Y. (2000). Hydrolysis and absorption in the small intestines of posthatch chicks. Poultry Science. 79(9), 1306-1310. doi: 10.1093/ps/79.9.1306.

Thomas, D. H. (1982). Salt and water excretion by birds: the lower intestine as an integrator of renal and intestinal excretion. Comparative Biochemistry and Physiology - Part A: Molecular \& Integrative Physiology, 71(4), 527-535. doi: 10.1016/0300-9629(82)90201-8.

Tran, T. S., Narcy, A., Carré, B., Gabriel, I., Rideau, N., Gilbert, H., Demeure, O., Bed'Hom, B., ChantryDarmon, C., Boscher, M. Y., Bastianelli, D., Sellier, N., Chabault, M., Calenge, F., Le Bihan-Duval, E., Beaumont, C., \& Mignon-Grasteau, S. (2014). Detection of QTL controlling digestive efficiency and anatomy of the digestive tract in chicken fed a wheatbased diet. Genetics Selection Evolution, 46(1), 25. doi: 10.1186/1297-9686-46-25.

Trifonov, G. A., \& Kuleshov, K. A. (2008). Postnatalnyiy morfogenez dvenadtsatiperstnoy kishki kur pri prime- nenii selensoderzhaschih preparatov. Vestnik Altayskogo gosudarstvennogo agrarnogo universiteta, 3(41), 33-36 (in Russian).

Uni, Z., Noy, Y., \& Sklan, D. (1999). Posthatch development of small intestinal function in the poult. Poultry Science, 78, 215-222. doi: 10.1093/ps/78.2.215.

van der Klis J. D., Verstegen M. W., \& De Wit W. (1990). Absorption of minerals and retention time of dry matter in the gastrointestinal tract of broilers. Poultry Science, 69(12), 2185-2194. doi: 10.3382/ps.0692185.

Watkins, E. J., Butler, P. J., \& Kenyon, B. P. (2004). Posthatch growth of the digestive system in wild and domesticated ducks. British Poultry Science, 45(3), 331-341. doi: 10.1080/00071660410001730824.

Yang, H., Lyu, W., Lu, L., Shi, X., Li, N., Wang, W., \& Xiao, Y. (2020). Biogeography of microbiome and short-chain fatty acids in the gastrointestinal tract of duck. Poultry Science, 99(8), 4016-4027. doi: 10.1016/j.psj.2020.03.040.

Yovchev, D., Dimitrov, D., \& Penchev, G. (2013). Age weight and morphometrical parameters of the bronze turkey's (Meleagris meleagris gallopavo) intestines. Bulgarian Journal of Agricultural Science, 19(3), 611614.

Zharova, E. Yu., \& Tkachev, A. A. (2007). Morfologyya tolstogo kyshechnyka kur krossa "Yza Braun". Ptycevodstvo, 10, 38-39 (in Russian). 